\title{
Evaluasi Program Peningkatan Profesionalisme Aparatur Pemerintahan Desa Rancamulya Kabupaten Sumedang
}

\author{
${ }^{1}$ Fadjar Trisakti, ${ }^{2}$ Herabudin, ${ }^{3}$ Zulfa Irnawati \\ ${ }^{1}$ Administrasi Publik Fakultas Ilmu Sosial Dan Ilmu Politik UIN Sunan Gunung Djati Bandung; \\ fajr3sakti@gmail.com \\ ${ }^{2}$ Administrasi Publik Fakultas Ilmu Sosial Dan Ilmu Politik UIN Sunan Gunung Djati Bandung; \\ Herabudin.herabudin@yahoo.co.id \\ ${ }^{3}$ Administrasi Publik Fakultas Ilmu Sosial Dan Ilmu Politik UIN Sunan Gunung Djati Bandung; \\ Zulfairnawati7@gmail.com
}

\begin{abstract}
This research is motivated by problems in village programs that have not been effective, the program is a village financial management training program and capacity building for the apparatus and facilitation of community empowerment. must go through several dimensions to improve the program effectiveness, efficiency, adequacy, leveling, responsiveness, the accuracy of the results of this evaluation which will later be used as input for the next village government apparatus. So that the researchers are interested in examining the Program for Professionalism Improvement of Village Government Apparatus with qualitative methods in a descriptive approach with good results. Because this can be maintained in implementing programs held by villages to improve the program to run effectively. It is better and more effective with what was done before, before the program. Because the program is indeed very important.
\end{abstract}

Keywords: Program Evaluation, Public Servant, Governmental Apparatus, Professionalism.

\section{Pendahuluan}

Dalam Permendagri RI Nomor 2 Tahun 2017 Tentang Standar Pelayanan Minimal Desa dalam Bab III Pasal 5 Standar, Pelayanan Minimal Desa, bahwa ada beberapa pelayanan yaitu, mengenai penyebarluasan informasi terkait pelayanan dan penyediaan, serta penyediaan suatu data dan informasi kependudukan juga pertahanan, mengefektifkan atau menyederhanakan suatu pelayanan, pemberian surat keterangan, dan pengaduan masyarakat. Desa salah satu bentuk daerah dalam penyelenggaraan otonomi daerah yang merupakan ujung tombak dalam pelayanan pemerintahan terhadap masyarakat sehingga dapat dikatakan bahwa keberhasilan penyelenggaraan pemerintahan daerah kabupaten atau kota tercermin pada keberhasilan pemerintahan di desa, keberhasilan itu tidak akan pernah tercapai tanpa adanya sebuah perencanaan yang merupakan suatu proses untuk mencapai tujuan yang ingin di capai.

Visi dari Desa Rancamulya, Berdasarkan keadaan hingga sekarang ini dan dengan melihat pertimbangan modal dasar ynag dimiliki, maka visi pembangunan Desa Rancamulya Tahun 2013 - 2018 adalah: "Rancamulya Semanis Madu Sejahtera Maju Agamis Mandiri Produktif". Melalui pelatihan dan pemberian kompensasi yang adil dan merata termasuk penyediaan berbagai fasilitas kesejahteraan aparat dapat meningkatkan kualitas SDM. Ada dua aspek yang menyangkuti pengembangan sumber daya manusia dalam menentukan kualitan 
SDM yaitu aspek fisik dan aspek non fisik yang menyangkut kemampuan kinerja, berfikir dan terampilan.

Dalam pelaksanaan pembangunan masih rendahnya kemampuan dalam perencanaan, berakibatkan pada kurangnya koordinasi antara output dan implementasi kebijakan kebutuhan masyarakat yang merupakan input dari kebijakan. Implementasi sejatinya diarahkan melalui berbagai kegiatan melalui program. Implementasi kebijakan adalah bagian yang sangat penting dalam struktur kebijakan. Bagian implementasi menentukan atau mengukur sejauh mana pengaplikasian yang dilakukan oleh pemerintah di lapangan sehingga dapat menghasilkan ouput dan outcomes seperti yang telah ditentukan sebelumnya. Dalam Perda Kabupaten Sumedang Nomor 13 Tahun 2007 Pasal 10 Tentang Tata Cara Penyusunan, Pengendalian dan Evaluasi Rencana Pembangunan Desa, yang didasarkan pada beberapa azas yaitu relevansi, efisiensi, efektivitas, berkelanjutan, transparan, akuntablitas, disiplin, dan partisipatif.

Suatu organisasi dapat berjalan dengan baik apabila bisa menjalankan tugas serta fungsinya secara efektif dan efisien, dengan kesesuaian kinerja dan kompetensi dari masingmasing aparatur sesuai dengan bidang yang ditugaskan serta dapat bersifat profesional. Oleh sebab itu menjadi tantangan pada setiap organisasi pemerintah termasuk pemerintahan desa. Strategi yang harus dilakukan yaitu pengelolaan aparatur untuk mewujudkan pelayanan yang optimal untuk pemberdayaan aparatur. Jadi hal ini dapat mengikutsertakan para aparatur disemua kalangan dalam pengambilan keputusan dan pemecahan masalah.

Secara umum istilah evaluasi memiliki arti yang sama dengan, pemberian angka (rating), penaksiran (appraisal) dan penilaian (assesment), istilah-istilah tersebut digunakan untuk melakukan suatu analisis dari hasil kebijkan yang dapat dinyatakan dalam ukuran nilai. Maknanya, yang lebih spesifik, evaluasi berkaitan dengan hasil produksi informasi atau output tentang nilai atau manfaat kebijakan. Saat hasil kebijakan pada nyatanya memiliki nilai, ini disebabkan karena hasil output mampu memberi sumbangan pada tujuan atau sasaran. Suatu kebiajakan atau program dapat dikatakan mencapai tingkat kinerja yang bermakna apabila, masalah-masalah kebijakan dibuat jelas atau diatasi.

Dunn (dalam Nugroho, 2009:536) mengemukakan kriteria-kriteria evaluasi kebijakan dalam enam tipe sebagai berikut:

a. Efektifitas

Efektifitas berhubungan dengan suatu alternatif yang diharapkan dapat mencapai hasil, pengaruh maupun akibat serta tujuan dari diadakannya tindakan tersebut. Berkenaan dengan itu efektifitas berkaitan dengan rasionalitas teknis, selalu diukur dari unit produk atau layanan atau nilai moneternya

\section{b. Efisiensi}

Persamaan antara efisiensi dengan rasionalitas ekonomi, dapat dilihat dari pola hubungan antara efektifitas dan usaha yang secara universal berangkat dari ongkos moneter. Tindakan ini dapat dilakukan dalam rangka meningkatkan efesiensi tertentu.

c. Kecukupan

Kepuasan kebutuhan terhadap suatu tingkat efektivitas dapat diukur melalui nilai atau kesempatan yang membuat suatu keadaan dimana masalah dibutuhkan. Penekanan yang dilakukan lebih kepada hubungan diantara alternatif atau pilihan kebijakan dengan hasil yang diharapkan. 
d. Pemerataan/Kesamaan

Hal yang memadai untuk mendistribusikan risorsis dalam masyarakat yakni konsep saling bersaing dengan kriteria kesamaan erat kaitannya dengan, pemerataan atau kewajaran dan terhadap konflik etis

e. Responsivitas

Kriteria responsivitas merupakan hal yang penting karen didalamnya mencakup semua kriteria seperti keefektifan, efisiensi, kecukupan, kesamaan, namun masih dibilang gagal jika belum menanggapi kebutuhan actual dari kelompok yang seharusnya disajikan dari adanya suatu kebijakan. Hal ini dikarenakan berkenaan dengan seberapa jauh suatu kebijakan dapat memberikan kepuasan terhadap berbagai aspek kebutuhan dalam kelompok masyarakat tertentu.

\section{f. Ketepatan}

Ketepatan mengacu terhadap nilai dan harga dari beberapa tujuan program dan terhadap asumsi yang menguatkan serta melandasi tujuan tersebut. Kriteria ketepatan dekat hubungannya dengan rasionalitas substantive, karena pertanyaan tentang ketepatan kebijakan tidak berhubungan dengan kriteria individu tertentu namun dua atau lebih kriteria secara bersama-sama.

Profesionalisme seorang aparatur dapat ditunjukkan dengan suatu kemampuan untuk dapat memahami kebutuhan masyarakat serta aspirasi dalam menjalankan kegiatan program pelayanan. Aparatur dituntut untuk memberikan pelayanan yang baik, adil, serta inklusif yang bukan hanya sekedar cocok dalam tempat penugasan. Siagian (2000:163) melihat profesionalisme sebagai cara dan sikap bagaimana aparatur dapat menjalani fungsi serta mengacu pada prosedur yang telah disederhanakan dengan cepat. Menurut pendapat tersebut, konsep profesionalisme dalam diri aparat dilihat dari segi:

a. Kreatifitas

Inovasi dapat dilakukan oleh aparatur untuk mengadapi suatu hambatan dalam memberikan pelayanan terhadap publik. Agar dapat mengurangi pemikiran miring masyrakat terhadap birokrasi publik yang kaku terhadap pengerjaannya. Aparatur yang kreatir dapat terbentuk jika: adanya kondisi atau iklim yang kondusif yang mampu memberikan dorongan keada aparatur oemerintah untuk menemukan ide serta konsep baru dengan penerapan yang inovatif. Adanya kerjasama antara pimpinan dan bawahan dalam pengambilan keputusan yang berkaitan dengan mutu hasil pekerjaan, pekerjaan, serta peyelesaian masalah dalam tugas.

b. Inovasi

Inovasi merupakan wujud dari suatu hasrat atau tekad untuk mencari, cara serta metode pengerjaan yang baru dalam melaksanakan tugasnya. Masalah dasar dalam perilaku inovatif ini adalah rasa puas terhadap pekerjaan yang telah dikerjakan atau dicapai.

c. Responsivitas 
Bagaimana aparatur dapat memberikan kemampuannya secara maksimal dan cepat agar dalam pengerjaan tugas dan fungsinya tidak tertinggal. Serta siap untuk mengantisipasi dan menghadapi segala pembaharuan dalam hal aspirasi, perkembangan, tuntutan maupun pengetahuan.

Aparatur pemerintah yang memberlakukan pemberdayaan dengan sebaik-baiknya akan menghasilka prestasi kerja ynag baik pula, yang pada akhirnya akan meningkatkan organisasi pemerintahan. Program yang dilakukan Desa Rancamulya yaitu meningkatkan kapasitas pemerintah desa dengan melakukan kegiatan seperti pelatihan, memberikan pendidikan, serta penyuluhan untuk kepala desa, perangkat desa, dan BPD (Badan permusyawaratan Desa).

Dengan permasalahan yang sebelumnya diadakakan program pelatihan pengelolaan keuangan desa bagi perangkat desa dan peningkatan kapasitas aparatur dan fasilitasi kader pemberdayaan masyarakat desa masih banyak beberapa kendala yang memang menjadi hambatan bagi kinerja aparatur desa kinerjanya masih belum optimal dan belum efektif.

\section{Tabel 1}

\section{Laporan Konsolidasi Realisasi Penyerapan Dan Capaian Output Dana Desa Sampai Dengan Tahap II Tahun Anggaran 2017-2018}

\begin{tabular}{|l|l|}
\hline \multicolumn{1}{|c|}{ Uraian } & \multicolumn{1}{|c|}{ Uraian Output } \\
\hline $\begin{array}{l}\text { Kegiatan Peningkatan Kapasitas } \\
\text { Kepala Desa, Perangkat Desa, BPD, } \\
\text { dan Lembaga Masyarakat }\end{array}$ & $\begin{array}{l}\text { Pelatihan Pengelolaan Keuangan Desa Bagi } \\
\text { Perangkat Desa }\end{array}$ \\
\hline $\begin{array}{l}\text { Meningkatkan kapasitas pemerintah } \\
\text { desa dengan melakukan kegiatan } \\
\text { seperti pelatihan, memberikan } \\
\text { pendidikan, serta penyuluhan untuk } \\
\text { kepala desa, perangkat desa, dan BPD } \\
\text { (Badan permusyawaratan Desa). }\end{array}$ & $\begin{array}{l}\text { Peningkatan Kapasitas Aparatur dan fasilitasi } \\
\text { pemberdayaan masyarakat desa }\end{array}$ \\
\hline
\end{tabular}

Sumber: Badan Permusyawaratan Desa Rancamulya, 2018

Masalah diatas memang penting untuk kita mengevaluasi program aparatur pemerintah desa untuk mengukur sejauh mana kinerjanya dan meningkatkan profesionalismenya. Evaluasi prorgram dilakukan untuk mengetahui seberapa besar tingkat keberhasilan yang dicapai dari ekgiatan yang telah direncanakan sebelumnya. Evaluasi program merupakan bagian dari suatu evaluasi kebijakan, karenai program merupakan turunan dari pelaksanaan kebijakan publik. Dalam pengimplementasian kebijakan publik, diantaranya ada dua pilihan langkah yang dapat diambil, sebagai berikut:

1. Diimplementasikan langsung melalui program, atau

2. Melakukan kegiatan yang merupakan formulasi turunan dari kebijakan publik tersebut.

Arah untuk menetapkan pengelolaan pemerintah pada tata kelola yang lebih baik serta reformasi birokrasi pada kebijakan pemerintah. Salah satunya untuk mewujudkan pemerintah yang baik dan meningkatkan keprofesionalan aparatur pemerintah baik dalam tingkat pusat maupun desa. Pengembangan kapasitas aparatur pemerintah desa perlu dilakukan untuk dapat meningkatkan kemampuan dalam memberikan pelayanan kepada publik. Upaya untuk mengatasi serta memperbaiki berbagai kelemahan dan perubahan lingkungan, maka harus 
melandaskan pemikiran terhadap permasalahan yang dihadapi tersebut seperti melakukan suatu evaluasi dalam pola pikir untuk membangun aparatur yang cakap dan profesional sehingga mampu melaksana kewajiban tugas dan fungsinya sebagai penyelenggara kegiatan pembangunan dan penyelenggara pelayanan publik.

Berdasarkan masalah-masalah yang telah duraikan diatas, maka dari itu penulis tertarik untuk melakukan penelitian di Kantor Desa Rancamulya Kabupaten Sumedang, yaitu dengan judul: Evaluasi Program Peningkatan Profesionalisme Aparatur Pemerintahan Desa Rancamulya Kabupaten Sumedang.

\section{Metode Penelitian}

Penelitian ini menggunakan pendekatan kualitatif dengan tipe penelitian deskriptif. Penelitian ini menyajikan suatu keadaan atau gambaran detail mengenai suatu kehidupan sosial dan untuk memberikan gambaran terhadap sifat maupun keaadaan gejala sosial yang terjadi dalam kehidupan masyarakat. Dalam penelitian ini, peneliti menggunakan dua sumber data yaitu sumber primer, yang merupakan suatu data atau dokumen yang didapatkan dari sumber pertama, dan sumber sekunder, yang merupakan data informasi yang terkumpul dari sumber kedua atau sumber yang telah ada. Untuk mengumpulkan data yang diperlukan dalam membahas permasalahan penelitian ini, maka penulis menggunakan data primer dengan teknik observasi dan wawancara, sedangkan data sekunder didapat dari instansi pemerintah terkait dengan penelitian ini. Tujuan penelitian dalam analisis adalah untuk memberikan batasan kepada peneliti agar penelitiannya lebih tersusun. Adapun tahap pengolahan data yang digunakan ada tiga yakni yang pertama reduksi data yang memfokuskan pada pokok permasalahan yang penting, lalu kedua penyajian data yang menggunakan teks naratif serta ketiga, penarikan kesimpulan dan verifikasi dimana dilakukan pengkajian ulang terhadap data yang didapat dilapang terhadap kecocokannya dengan teori yang digunakan sehingga dapat teruji validitasnya.

\section{Hasil Dan Pembahasan}

Hasil penelitian yang di dapatkan merupakan data yang sebenar-benarnya yang terjadi di lapangan yang disesuaikan dengan teori yang digunakan oleh peneliti yaitu mengguakan teori Evaluasi Kebijakan menurut Dunn (2000:608). Berbagai permasalahan mendasar yang dihadapi pemerintah Desa Rancamulya Kecamatan Sumedang Utara Kabupaten Sumedang apabila tidak ditangani secara sungguh-sungguh, maka hal ini akan berpotensi terhadap kurangnya kepercayaan masyarakat terhadap pelayanan pemerintahan desa. Oleh karena itu permasalahan yang mendesak menjadi prioritas untuk dilaksanakan. Beberapa kebijakan telah diambil selama kurun waktu 1 (satu) tahun terakhir pada upaya-upaya peningkatan penerapan prinsip-prinsip tata pemerintahan desa yang baik, efektif dan efisien berdasarkan prinsipprinsip transparansi, akuntabilitasi dan partisipatif pada semua kegiatan antara lain melalui langkah-langkah:

a. Penataan dan peningkatan budaya kerja dan kapasitas SDM perangkat desa yang berbasis kompetensi agar lebih propesional, produktif dan bertanggungjawab sesuai 
dengan apa yang telah menjadi tugas serta fungsinya dalam memberikan pelayanan kepada masyarakat.

b. Peningkatan kualitas pelayanan publik terhadap masyarakat

c. Penataan ketatalaksanaan pemerintah desa melalaui penataan manajemen administrasi desa.

d. Meningkatkan IPTEK sera kemajuan infrastruktur pendukung pelayanan publik.

Data penelitian ini diperoleh pada saat penelitian berlangsung di lapangan. Dalam penelitian ini, peneliti meneliti mengenai Evaluasi Program Peningkatan Profesionalisme Aparatur Pemerintahan Desa Rancamulya yang terdiri dari 2 (Program) program Pelatihan Pengelolaan keuangan desa Bagi Aparatur Desa dan Peningkatan Kapasitas Aparatur dan Fasilitasi Kader Pemberdayaan Masayarakat Desa.

\section{Efektifitas}

Suatu pilihan atau alternatif sebagai suatu hasil atau output sesuai dengan apa yang diharapkan dalam mencapai tujuan melalui suatu tindakan yang terencana. Hubungan atau keterkaitan antara efektifitas dengan rasionalitas teknis, dilihat dari produk atau layanan yang diberikan. Dalam program pengelolaan keuangan desa bagi aparatur desa sesuai apa yang diharapkan desa dan yang direncanakan desa tentang pengelolaan keuangan desa rancamulya sudah berjalan efektif, berarti sudah ada tujuan apa yang diharapkan oleh desa rancamulya itu sendiri. Masih ada yang berbicara dalam program pelatihan pengelolaan keuangan desa dengan tujuan-tujuan yang memang diharapkan sebelumnya atau yang sudah direncanakan oleh desa, memang masih kurang efektif hasil yang telah diprediksi sebelumnya, hal ini disebabkan karen atindakan yang kurang maksimal.

Dari hasil yang peneliti telah teliti dapat disimpulkan bahwa pelatihan pengelolaan keuangan desa bagi aparatur desa memang belum berjalan dengan efektif. Hal ini dikarenakan masih adanya kendala-kendala yang memang perangkat desa harus diperbaiki atau lebih ke di adakannya pelatihan-pelatihan atau bimbingan-bimbingan yang sesuai dari pemerintahannya agar dapat berjalan dengan efektif atau berjalan dengan maksimal program tersebut. Dengan adanya program kedua Dalam program peningkatan kapasitas aparatur dan fasilitasi pemberdayaan masyarakat memang desa berharap apa yang direncanakan oleh desa untuk mencapai hasil yang di harapakan desa itu berjalan dengan maksimal, atau tidak ada kendalanya bagi aparatur desa yang sudah mengikuti program peningkatan kapasitas aparatur dan fasilitasi pemberdayaan masyarakat.

Dalam pelaksanaannya program ini sudah dibilang efektif dalam menjalankan program yang direncanakan oleh desa rancamulya. Peneliti mendapat data tentang permasalahan peningkatan kapastias aparatur dan fasilitasi pemberdayaan masyarakat memang dikatakan sudah efektif sudah lebih baik dengan apa yang dilakukan sebelumnya, sebelum adanya program tersebut, karena program peningkatan kapasitas aparatur dan fasilitasi pemberdayaan masyarakat memang sangat penting untuk ditingkatkan. Dalam teori Dunn efektifitas itu sejauh mana kita dapat merencanakan atau tujuan-tujuan kita yang diharapkan tepat sasarannya dengan apa yangkita harapkan. berarti sudah memenuhi penjelasan dari teori efektifitas atau memang masih kurangnya keefektifan dalam program tersebut. 


\section{Efisiensi}

Efisiensi yang merupakan persamaan dari rasionalitas eknomi, yang merupakan hubungan antara efektifitas dan usaha yangakhirnya berangkat dari keadaan moneter. Dalam hal ini yang berkaitan dengan tumbuhnya jumlah usaha yang dibutuhkan untuk peningkatan efektifitas tertentu. Efisiensi juga terdapat perbandingan yang terkait dengan pemasukan serta penegluaran, sama hal nya dengan hasil maksimal yang telah dicapai dalam penggunaan sumber terbatas. hubungannya apa yang telah diselesaikan dalam program tersebut.

Terdapat beberapa permasalahan dalam desa sebelum adanya program pengelolaan keuangan dengan kurangnya SDM pada aparatur, tetapi aparatur harus bisa menjalankannya dengan cara perlahan untuk menggali apa permasalahan dalam kualitas SDMnya. Aparatur itu harus bertanggun jawab, pembangian kerja nyata, prosedur kerja yang praktis, rasionalitas wewenang, jika aparatur ingin tercapainya efisiensi tersebut. dan pastinya desa rancamulya ingin lebih baik dari sebelumnya ingin bisa menjalankan tugas dan fungsinya dengan baik.

Dapat disimpulkan bahwa permasalahan kualitas SDM itu memang sekarang-sekarang sudah maju sudah meningkat dari sebelumya dan dengan adanya SISKEUDES itu dapat membantu berjalannya tugas dan fungsi aparatur desa dengan memudahkan untuk menginput datanya. Dengan cara untuk meningkatkan kembali program tersebut untuk mencapai efisiensinya yang di harapkan desa maka lakukanlah dengan benar program tersebut. Jadi dalam pembahasan efisiensi berkaitan denga efektif kita harus melakukan efisiensi yang dalam pengerjaannya harus menggunakan sumber yang sesuai dengan adanya, namun efisiensi tidak terlalu terfokus pada apa yang menjadi tujuan tersebut. Untuk itu selain efisien kitapun harus juga efektif dalam menjalankan sesuatu sesuai dengan apa yang diharapkan.

\section{Kecukupan}

Suatu tingkatan efektifitas berkaitan jauh dengan kepuasaan kebutuhan, kesempatan serta nilai yang dimana masalah itu dibutuhkan. Kriteria kecukupan lebih menekankan pada suatu keterikatan antara alternative atau pilihan kebijakan serta hasil sebagaimana yang diharapkan. Dalam program desa Rancamulya ini tentang pelatihan pengelolaan keuangan desa rancamulya, dengan diadakannya program tersebut harapan atau kriteria kecukupannya dapat kuat dalam hubungan alternative kebijakannya dan hasil yang diharapkan oleh desa, agar dapat memenuhi apa yang diinginkan aparatur desa rancamulya yang sejahtera.

Sesuai dengan teori yang peneliti ambil dari Willian N Dunn alternative kebijakan dan sebagaimana hasil yang diharapkan oleh desa, kedua hal tersebut merupakan hal yang ditekankan dalam kriteria kecukupan. Dengan meningkatkan program tersebut aparatur lebih baik dalam pengelolaan keuangan desa, agar tidak disangka dana desa itu cair tetapi tidak ada hasilnya untuk kemasyarakat atau ke desanya pun. Karena dari sebelum sebelumnya memang belum memenuhi apa yang diharapkan oleh desa itu sendiri, dan sekarang sudah diganti dengan aparatur yang mungkin lebih bisa menata pengelolaan keuangan desa dengan baik.

Dana desa yang bersember dari APBN untuk desa dipergunakan untuk membangun serta membangkitkan pemberdayaan masyarakat serta untuk mendanai kebutuhan penyelenggaraan pemerintah desa maupun kemasyarakatannya. Dana desa ini sangat penting untuk implementasi alokasi dana desa agar dapat jelas pemakaiannya dan pelaksanaan yang sempurna. Dana desa pun untuk meningkatkan kualitasdengan adanya sarana dan infrastruktur 
yang mana akan mensejahterakan masyarakat desa. Memang desa rancamulya sudah meningkatkan pengelolaan keuangannya dengantidak yang lebih baik dan efektif.

\section{Perataan}

Indikator ini berkaitan erat dengan suatu rasionalitas sesuai dengan aturan yag telah ditetapkan dan social yang tertuju padasuatu distribusi atau asupan akibat serta usaha yang berbeda dari berbagai kelompok masyarakat. Kriteria kesamaan merekomendasikan untuk merancang suatu kesempatan mendistribusikan pendapatan, kemudian pendidikan ataupun kesempatan mendapatkan pelayanan publik yang baik. Pelayanan publik merupakan suatu bentuk kegiatan yang mengahsilkan barang dan jasa yang diselenggarakan oleh lembaga daerah serta lingkungan badan usaha milik Negara, karena sebagai kewajian yang harus dilakukan oleh lembaga penyediaan pelayanan publik dan sebagai suatu kegiatan atas terwujudnya aturan atau ketentuan peraturan perundang-undangan. Pelayanan publik masih banyak yang harus dievaluasi harus dilakukan karena kebutuhan masyarakat semakin meningkat dan beranekaragam.

Peningkatan pelayanan publik di desa rancamulya mulai ditingkat kan sedikit demi sedikit, karena pelayanan public memang sangat lah penting bagi lembaga terkait, bila pelayanannya tidak memuaskan masyarakat pun merasa risih dengan pelayanannya, maka dari itu pedoman yang ada di desa dilakukan dengan sebaik mungki. Dan kemampuan dalam pelayanan public mungkin masih perlunya ditingkatkan dalam pengetahuan atau diadakannya pelatihan-pelatihan untuk pelayanan publik.

\section{Responsivitas}

Suatu kebijakan masih dikatakan gagal jika mengabaikan beberapa unsur seperti keefektivan, efisiensi, kebutuhan yang cukup dalam memberi pelayanan atau tanggapan suatu kepentingan kelompok maupun individu yang mestinya diaplikasikan berdasarkan kebijakan yang telah dibuat, kebijakan yang dapat memuaskan suatu kebutuhan ataupun preferensi dari sekelompok masyarakat atau individu lainnya harus melihat atau merujuk pada kriteria responsivitas. Hal ini sangat penting karena menjadi acuan atau rujukan atas kepuasaan kebutuhan yang didapatkan oleh sekelompok masyaraka maupun individu.

Responsivitas kepekaaan yang diberikan oleh desa yang dimana pemerintahan menyelenggarakan pelayanan, dalam responsivitas ini memang berkaitan dengan efektivitas, efisiensi, kecukupan. Bila memang dalam program pengelolaan keuangan desa dan peningkatan kapasitas aparatur masih terdapat kegagalan ya mungkin belum terpenuhi rencana yang diharapkan. Memang masih adanya kendala dalam bagaimana menjalankan tupoksi yang baik dan benar agar kinerja aparatur pemerintah desa lebih baik dengan menjalankan tugas nya dan tidak dapat kecurangan dalam melaksanakan rencana apapun. Jadi, belum adanya responsivitas yang mendukung dalam aparatur pemerintah desa rancamulya ini.

Dalam pengelolaan keuangan desa memang desa harus lebih hati-hati lagi dengan kinerjanya harus lebih teliti bila memang ingin berjalan dengan baik pengelolaan keuangan desan dengan diadakan system keuangan desa yang baru di terapkan 3 tahun kebelakang memang membantu terhadap aparatur pemerintahan desa dengan adanya system tersebut, tetapi masih ada permasalahan dalam kebijakan tersebut. 
Dalam pegelolaan keuangan desa masih banyak nya masalah dalam pengelolaannya dan masyarakat memang belum paham dengan peraturan kebijakan desa rancamulya tersebut, jadi apa yang seharusnya rencana desa seperti ini tetapi malah masyarakat membuat rencanarencana yang jauh dari perkiraan desa tersebut karena masyarakat banyak keinginan yang belum tercapai jadi banyak nya alasan-alasan yang dilontarkan masyarakat kepada desa pada pelaksanaan musyawarah.

\section{Ketepatan}

Ketepatan kebijakan tidak berhubungan dengan karakteristik masing-masing individu, namun melibatkan dua atau lebih individu lain secara bersamaan. Kriteria ketepatan dilihat dari dekat hubungannya dengan pemikiran yang rasional atau disebut rasionalitas subtantive. Hal ini mengacu pada suatu nilai atau harga atas berjalannya program-program tersebut dan dikaitkan pada kekuatan asumsi yang menjadi dasar dari program itu. Desa Rancamulya membuat visi dan misi untuk melancarkan tujuan yang ingin dicaapi dalam rentang waktu enam tahun yang disajikan dalam program pelatihan pengelolaa keuangan desa dan peningkatan kapasitas aparatur dan fasilitasi pemberdayaan masyarakat. Dan dalam Misi desa rancamulya Misi merupakan penjabaran dari visi merupakan hal yang menggambarkan tentang bagaimana cara agar tujuan darai visi dapat terlaksanakan yang telah ditetapkan atau sesuatu yang harus dilaksanakan oleh desa untuk mencapai visi desa.

Dengan adanya program pelatihan pengelolaan keuangan desa dengan program peningkatan kapasitas aparatur dan fasilitasi pemberdayaan masyarakat, hal ini sudah sesuai dengan runtutan apa-apa yang dijabarkan dalam visi serta misi yang telah direncanakan sebelumnya oleh desa rancamulya. Ketepatan dalam tujuan desa yang diharapkan tepat sasarannya pada program tersebut. Jadi profesionalisme kerja dalam program pengelolaan keuangan aparatur desa yang mempengaruhi sumber daya memang ada permasalahan dalam kualitas kerja aparatur, masih belum berjalan dengan maksimal pengelolaan keuangan desa bagi aparatur pemerintahan, memang masih perlu evaluasi program peningkatan profesinalisme aparatur pemerintah desa rancamulya, karena masih kurang dalam pemberdayaan aparatur dan tugas yang dilaksanakan aparatur masih belum memenuhi apa yang program itu direncanakan hanya mengikuti saja pelatihan-pelatihan dan tidak selamanya diterapkan pada aparatur pemeritah desa rancamulya.

Dalam pengembangan kapasitas aparatur dalam fasilitasi pemberdayaan masyarakat aparatur masih meningkatkan atau mencoba perlahan untuk meningkatkan pemberdayaan masyarakat, karena aparatur selalu menjalankan tugas yang di perintah oleh pemerintahan apa yang harus dilaksanakan terdahap masyarakat dan program apa yang harus diadakan dalam pemberdayaan kepada masyarakat agar memenuhi keinginan masyarakat yang memang belum tercapai oleh masyarakat.

\section{Simpulan}

Seperti yang telah diuraikan diatas yakni dilihat dari hasil penelitian dan juga pembahasan sebelumnya, peneliti bisa menarik kesimpulan bahwa Evaluasi Program Peningkatan Profesionalisme Aparatur Pemerintah Desa secara universal sudah berjalan dengan semenstinya yakni lebih efektif, namun jika dilihat dari berlangsungnya beberapa program yang dilaksanakan masih perlu diperbaiki atau dievaluasi. Profesionalisme kerja 
dalam program pengelolaan keuangan aparatur desa yang mempengaruhi sumber daya memang ada permasalahan dalam kualitas kerja aparatur, tetapi dengan berjalannya waktu sudah berjalan dengan baik. Dalam pengembangan kapasitas aparatur dalam fasilitasi pemberdayaan masyarakat aparatur masih meningkatkan atau mencoba perlahan untuk meningkatkan pemberdayaan masyarakat, karena aparatur selalu menjalankan tugas yang di perintah oleh pemerintahan apa yang harus dilaksanakan terdahap masyarakat dan program apa yang harus diadakan dalam pemberdayaan kepada masyarakat agar memenuhi keinginan masyarakat yang memang belum tercapai oleh masyarakat.

\section{Referensi}

Agustino, L. (2008). Dasar- dasar Kebijakan Publik. Alfabeta: Bandung

Anggara, S. (2014). Kebijakan Publik.Bandung: Cv Pustaka Setia.

Dunn, W. (2003). Pengantar Analisis Kebijakan Publik. Gadjah Mada University Press: Yogyakarta.

Indiahono, D. (2009). Kebijakan Publik Berbasis Dynamic Analiysis. Gava Media: Yogyakarta.

Islamy, I. (2009). Prinsip- prinsip Perumusan Kebijaksanaan Negara. Bumi Aksara: Jakarta.

Keban, Y. (2004). Enam Dimensi Strategis Administrasi Publik Konsep dan Teori. Gava Media: Yogyakarta.

Kusumanegara, S. (2010). Model dan Aktor Dalam Proses Kebijakan Publik. Gava Media: Yogyakarta.

Nawi, R. (2017). Perilaku kebijakan Organisasi. Bandung: CV Sah Media.

Nugroho, R. (2009) Kebijakan Publik: Formulasi, Implementasi dan Evaluasi. Jakarta, PT. Elex Media Kompetindo.

Parsons, W. (2005). Public Policy: Pengantar Teori dan Praktik Analisis Kebijakan. Prenada Media: Jakarta.

Pasolong, H. (2014). Teori Administrasi Publik. Bandung: Alfabeta.

Santoso, P. (2009). Administrasi Publik, Teori dan Aplikasi Good Governance. PT. Refika Aditama: Bandung.

Siagian, S.P. (1994). Administrasi Pembangunan. Jakarta, 2000: Bumi Aksara.

Silalahi, U. (2012). Metode Penelitian Sosial.Bandung: PT Refika Aditama.

Sugiyono. (2012). Metode Penelitian Administrasi. Bandung: CV. Mandar Maju.

Wahab, S.A. (2004). Analisis Kebijaksanaan; Dari Formulasi ke Implementasi Kebijaksanaan Negara. Bumi Aksara: Jakarta.

Winarno, B. (2012). Kebijakan Publik (Teori, Proses, dan Studi Kasus). Buku Seru: Yogyakarta.

Wiyoto, B. (2005). Riset Evaluasi Kebijakan: Mitos Ketakutan Birokrasi, Instrumen, Strategic, Good Governanace. Bucetid Malang: Malang. 